DOI https://doi.org/10.30525/978-9934-26-046-9-48

\title{
ПРОПОЗИЦЇ̈ ЩОДО ПРОЕКТУВАННЯ ТА БУДІВНИЦТВА ЖИТЛОВИХ БУДИНКІВ У СКЛАДНИХ ІНЖЕНЕРНОГЕОЛОГІЧНИХ УМОВАХ У МІСЬКІЙ ЗАБУДОВІ
}

\author{
Трофимович Н. В. \\ член-кореспондент Академії будівництвва Украӥни, \\ кандидат технічних наук, старший науковий співробітник, \\ доцент кафедри архітектурних конструкиій \\ Начіональна академія образотворчого мистецтвва і архітектури \\ м. Київ, Украӥна
}

Актуальність проведеного автором дослідження та його аналізу підтверджується необхідністю розробки заходів запобігання аваріям та пошкодженню будинків існуючої забудови під час спорудження об’єктів новоЇ забудови у місті Києві, а також і в інших містах і селищах України.

В місті Києві почастішали аварії існуючих будинків попередніх років внаслідок порушень забудовниками нормативних вимог України у галузі будівництва під час проектування та спорудження об *єктів у щільній міській забудові.

Відомо, що грунтові умови України для потреб будівництва на 70\% території є складними. Це просідаючі грунти, зони зсувів, подроблювані території, сейсмічно небезпечні райони, карст тощо.

В зв’язку з цим, будівельні компанії та корпорації при спорудженні нових об'єктів, обирають , як правило,буронабивні палі великої довжини та діаметру. Вважається, що підошва палі потрапляє на грунт 3 достатньою несучою здатністю, а слабкі грунти для передавання зусиль від системи «будівля -фундамент» не будуть задіяні. Завдяки використанню паль великої довжини при проектуванні будинків підвищеної поверховості , як правило, нехтують врахуванням рівня грунтових вод, який в Україні досить високий. При цьому, вважається, що у гірській місцевості про рівень грунтових вод, взагалі можна забути, хоча наявність джерел та струмочків свідчить про зворотнє. Також не береться до уваги те, що більшість існуючої забудови споруджені на фундаментах мілкого закладення(стрічкових , стовпчастих, плитних) або з використанням забивних паль(стійок та підвісок) у попередньо підготовлених котлованах з улаштуванням дренажних 
заходів для зниження впливу грунтових та поверхневих вод. Виходячи 3 викладеного, майже кожний випадок появи великої кількості води можна було проаналізувати та, при бажанні, виявити причину. Деякі техногенні аварії (Волго-Донськ, Дніпропетровськ, Харків) були вивчені, проаналізовані та розроблені заходи запобігання таким явищам. Однак, зараз вважається, що, чим більше довжина буронабивної палі, тим надійніше споруда. Хоча зсув цілого массиву у Дніпропетровську показав, що мульди зсуву ще ніхто не відміняв!. Вони виникають у таких місцях, де водяні струмочки знаходять шлях і починають вимивати дрібні пильоваті часточки грунту, утворюючи шар змазки і зменшення сил тертя, після чого верхній массив грунту, привантажений забудовою, починає зміщуватись. Наслідки для будинків та споруд, при цьому, непередбачувані!

При цьому,не дуже ретельно аналізуються конструктивні схеми будинків старої забудови.особливо, це торкається великопанельних будинкків або будинків із 3 панелями перекриттів та покриттів 3 цегляними i блоковими стінами. Відсутність додаткових поясів жорсткості викликає деформування конструкцій стінами Відсутність додаткових поясів жорсткості викликає деформування конструкцій.

Наведу приклад пошкоджень 5-ти поверхового трисекційного цегляного будинку за адресою Тбіліський пров.За в м.Києві. Внаслідок не врахування усіх факторів підрядною Будівельною організацією ( а саме, не здійснений ретельний аналіз грунтових умов у зоні можливих зсувів, з вивченням змінних напрямків підземних вод шляхом улаштування додаткових скважин, не надано правильну оцінку несучій конструктивній системі п'ятиповерхового цегляного трисекційного будинку з шатровими панелями перекриттів, наявністю перепаду висоти фундаментів в середині, що було пов'язано з вбудованою котольнею у 1967 році, яка була не демонтована повністю та та аркою на краю ) під час проектування та будівництва 25-поверхового будинку з підземним паркінгом за адресою пров. Тбіліський $1 / 26$ (вул. Шулявська, 32) в м. Києві (Шевченківський район), в існуючому будинку 3'явились шпарини у несучих поздовжніх 3-х стінах на усі 5 поверхів та в усіх перекриттях у 2-х місцях, а саме: всередині будинку-на відстані 21,0 м та на відстані 9,0 м від торцьової стіни, тобто будинок розколовся у двох місцях і відокремлена частина почала зповзати в напрямку нового будівництва.. Також всі шпарини об'єднані зі шпаринами у перекриттях. (Фото 1, 2.) 


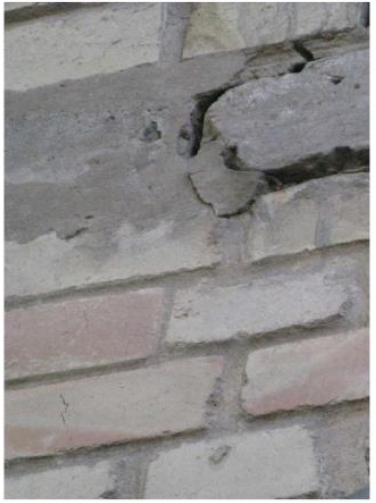

1

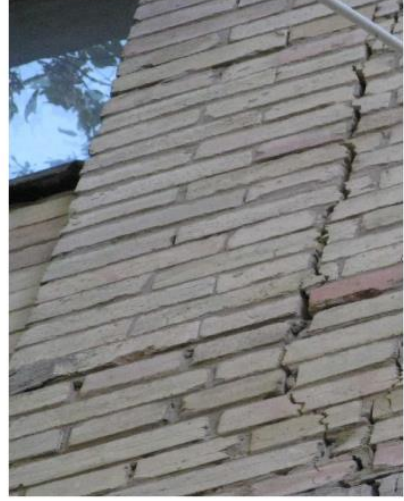

2

В зв'язку, з появою аналогічних пошкоджень в інших місцях Києва, з метою розробки узагальненого підходу до запобігання аналогічним аварійям та збереженню житлового фонду та інших видів міської існуючої забудови, сформований перелік найбільш важливих порушень.

Фактори, що призвели до розлому вказаного будинку у декількох місцях на висоту п'яти поверхів:

1. Не було здійснено попереднє обстеження вказаного будинку, що $\epsilon$ обов'язковим при новому будівництві на невеликій відстані від існуючого об'єкту. Як правило забудовник, посилаючись на брак коштів, не замовляє спеціалізованим організаціям обстеження навколишніх будинків. Таким чином, внаслідок візуального огляду представниками забудовника було зроблено помилкові висновки. Перемички над вікнами в цегляному будинку були сприйняті як монолітний по поверховий залізобетонний пояс. Також не було проаналізовано заміну під час спорудження будинку за адресою Тбіліський пров.3 а коло порожнистих панелей перекриттів на шатрові панелі, за винятком перекриттів над підвалом. Зазначена заміна суттєво змінила характер напруженодеформованого стану будинку в цілому, що передбачав до заміни-несучі поздовжні стіни та жорсткі диски перекриттів. Як відомо, шатрові панелі спираються за контуром, а не поздовжніми боками. Помилкові висновки призвели до відсутності забезпечення при проектуванні нового об*єкту спеціальних заходів захисту та підсиленню конструкцій цегляної трисекційної п*ятиповерхівки за адресою: місто Київ Тбіліський пров. 3 а. 
2. Не було здійснено перевірку стійкості грунтів основ та існуючих фундаментів цегляного будинку при відкопуванні котловану. Помилкові висновки представників забудовника базувались на обмеженій кількості шурфів, які були розташовані на значній відстані від існуючого будинку. Це призвело до неможливості встановлення місцезнаходження водо насичених та слабких шарів грунту безпосередньо під існуючим будинком і вжити необхідні заходи щодо запобігання нерівномірним осіданням основ і фундаментів.

3. Не було враховано вплив на основу та фундаменти існуючого будинку будівельного та постійного водозниження при виконанні робіт у котловані Не точні висновки забудовника призвели до виникнення суфозійних процесів під час рясних дощів та вичавлюванню грунтів основи існуючого будинку в бік котловану нової забудови, а також виникненню неконтрольованих процесів осадок існуючого будинку.

4. Не було влаштовано шпунтову стінку(внаслідок недостатнього обгрунтування можливих наслідків витиснення грунту 3-під плями існуючого будинку, економії коштів забудовником), що $\epsilon$ обов'язковим при більшому, ніж нормованому, розрахунковому осіданні нового будівельного об'єкту, що будується на відстані менше 20 м від існуючого, а також підошва залягання існуючого об'єкту вище відмітки підлоги підвального приміщення нового. Помилкові висновки призвели до катастрофічного осідання фундаментів існуючого будинку і утворенню численних наскрізних тріщин на всю висоту будівлі

5. До початку будівельних робіт не було здійснено перевірку дії динамічних впливів при влаштуванні віброзанурюваних пальових фундаментів 2-ма агрегатами на відстані менше 20 м від торцьової стіни існуючого будинку. Помилкові висновки будувались на вигідних економічних показниках, а саме: використання двох агрегатів разом було суттєво дешевше, ніж одного протягом більш тривалого часу.

6. Край котловану на відстані менше 5,0м м від існуючого будинку взагалі нічим не був закріплений і грунт вичавився 3-під існуючого будинку в бік котловану. Це відбулося внаслідок помилкових висновків з боку представників забудовника щодо підвищеної несучої здатності існуючого будинку за адресоюм.Київ, Тбіліський пров.За. Тобто вважалось, що поява мульди осідання грунту не призведе до осадок фундаментів та будинку в цілому. Помилкові висновки базувались на невірній оцінці конструкцій фундаменту та підвалу представниками 
забудовника. В дійсності, фундаменти існуючого будинку блокові мілкого закладення, мають суттєвий перепад висоти всередині будинку, стіни підвалу цегляні, несучі у дві цеглини, а перегородки у половину цеглини, що аж ніяк не можна вважати монолітною фундаментно-підвальною частиною.

Таким чином, економія на проведенні необхідних заходів, що передбачені нормативними вимогами в галузі будівництва України при спорудженні нових об* єктів, призвела до необхідності здійснювати усі конструктивні заходи з підсилення несучих конструкцій надземної та підземної частин будинкув м.Києві на Тбіліському пров.3 а, а також доцільно улаштовувати шпунтову стінку. Безумовно, будуть додаткові витрати на конструктивний та косметичний ремонт пошкоджених приватних осель та під*їздів.

Враховуючи викладене, надамо короткий перелік необхідних заходів, які повинен передбачити забудовник при спорудженні нових об*єктів у складних інженерно-геологічних умовах.

1. Здійснення попереднього обстеження існуючої в безпосередній близькості забудови, що $є$ обов'язковим при новому будівництві на невеликій відстані від існуючого об'єкту.

2.3дійснення перевірки стійкості грунтів основ та існуючих фундаментів старої забудови з метою визначення конструктивної системи «основа-будинок» перед початком улаштування котловану.

3.Врахування впливів на основу та фундаменти існуючої забудови будівельного та постійного водозниження при виконанні робіт у котловані. За необхідності. Передбачити заходи дренажу.

4.Влаштування шпунтової стінки між існуючим будинком і новою забудовою, що є обов'язковим при більшому, ніж нормоване, розрахункове осідання нового будівельного об'єкту, що будується на відстані менше 20 м від існуючого, а також підошва залягання існуючого об'єкту вище відмітки підлоги підвального приміщення нового.

5. Проведення додаткових динамічних досліджень, у випадку здійснення будівельних робіт із залученням агрегатів динамічної дії, до початку будівельних робі,т в напрямку перевірки дії динамічних впливів на несучі конструкції існуючої забудови і здійснення зазначеного контролю весь час при роботі вказаних механізмів на відстані менше 20 м від стіни існуючого будинку.

6.Обов*язкове закріплення краю котловану, який за проектом передбачено на відстані менше 5,0м м від існуючого будинку. 


\section{Література:}

1. ДЕРЖАВНІ БУДІВЕЛЬНІ НОРМИ УКРАЇНИ Система забезпечення надійності та безпеки будівельних об'єктів

2. ДБН В.1.2-2:2006 Навантаження і впливи .

3. ДБН В.1.2-14:18 .1Загальні принципи забезпечення надійності та конструктивної безпеки будівель і споруд

4. ДБН В 1.1-46:2017. Інженерний захист територій, будівель і споруд від зсувів та обвалів. Основні положення. 